ionic changes in response to APS. These findings suggest that under stressful situations, APS, like acetylsalicylic acid, breaks down the gastric mucosal barrier resulting in acid back diffusion and so induces readily observed damage to the stomach of rats. Whether or not the irritative property of APS on the gastric mucosal barrier in rats is related to the noxious action of the agent on the colon of guinea pigs and rabbits is now under investigation.

\title{
REFERENCES
}

1) Biaveir, R.G. AND COOK, D.L.: Gastroenterology 47, 409 (1964); 2) Zimmov, D.S., MiLLfR, G., Cox, G. ANd Tesler. M.A.: Gastroenterology 56, 19 (1969): 3) WatT, J. AND Marcls, R.: J. Pharm. Pharnacol. 24, 68 (1972); 4) Marces, R. And WATt, J.: Gastroenterology 67, 473 (1974); 5) TakeUChi, K., OKabe, S. and Takagi. K.: Am. J.dig. Dis. (in press): 6) Takagi, K. And Okabe, S.: Japan. I. Phamacol. 18,9 (1968): 7) Anson, M.L.: J. gen. Physiol. 22, 79 (1938); 8) Okabf, S., Honda, K., TAkeurhi, K. and Takagr, K.: Am. J. dig. Dis. 20, 626 (1975)

\section{EFFECTS OF BILATERAL OLFACTORY BULB ABLATIONS ON THE POLYAMINE LEVELS IN RAT BRAIN}

\author{
Tsukasa SAKURADA, Masayuki IMAI, Takeshi TADANO \\ and Kensuke KISARA \\ Department of Chemical Pharmacology. Tohotu College of Pharmacy, \\ Komatsushima, Sendai 983 , Japan
}

Accepted April 19, 1976

Spermidine (SPD) and Spermine (SPM) in the mouse brain have been found to increase both after olfactory bulb ablations and after long-term isolation $(1,2)$; however, changes in the brain polyamine concentrations in rats with bilateral offactory bulb lesions (O.B. lesioned rats) are still unknown. Changes in polyamine concentrations in different regions of $O$. B. lesioned rats are reported herein.

Male Wistar strain rats weighing 180 to $250 \mathrm{~g}$ at the time of olfactory bulb ablations were anesthetized with $45 \mathrm{mg} / \mathrm{kg}$ of sodium pentobarbital given i.p., then restrained in a stereotaxic instrument. The olfactory bulbs were bilaterally aspirated by suction pump after the scalp was incised, then openings were drilled over the bulbs and the dura cut. More than two thirds of the olfactory bulbs was removed and some parts of olfactory nuclei were also lesioned. All O.B. lesioned rats were individually housed in plastic cages $(46 \times 34 \times 17$ $\mathrm{cm}$ ) and given food and water ad libitum. The temperature and humidity was kept as constant as possible.

Rats were decapitated at 10 a.m. 4 weeks after surgery, the brains were rapidly removed and dissected into seven different regions according to the method of Glowinski and Iversen (3). Tissues from 4 animals were pooled for each of the other regions, except that one animal was used for the cortex. Separation of SPD and SPM was performed according to the 


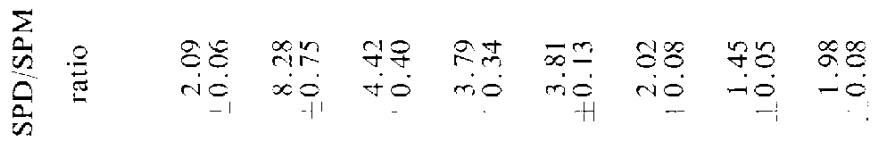

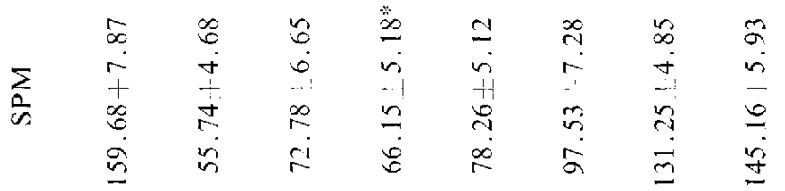

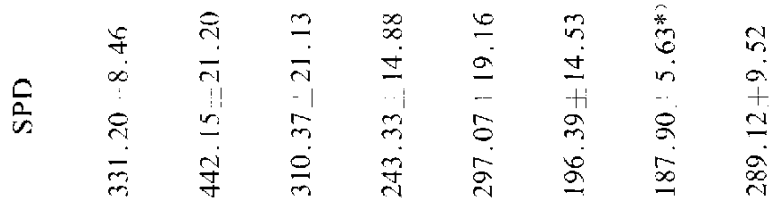

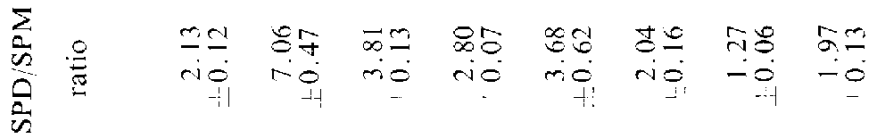

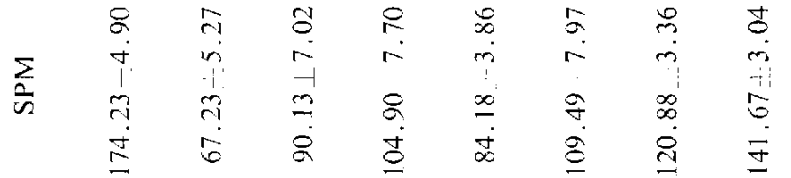

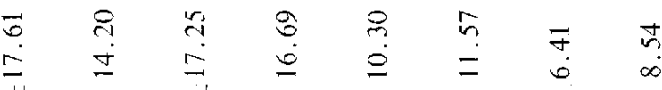

$\vec{s}$
$\infty$
-

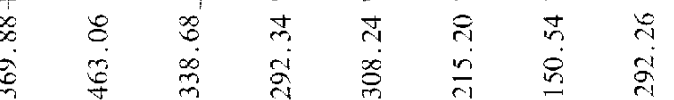

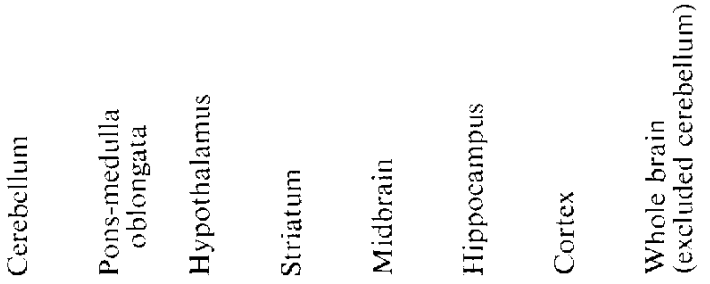


method of Endo and Ogura (4). SPD and SPM were assayed by TNBS reaction according to Satake et al. (5).

The results are summarized in Table 1. The concentrations of SPD and SPM in the whole brain of unoperaled controls was $144.56 \quad 4.76 \mathrm{nmole} / \mathrm{g}$ and $145.16 \pm 5.93 \mathrm{nmole} / \mathrm{g}$, respectively. Both SPD and SPM concentrations in O.B. lesioned rats did not show a significant difference compared with unoperated controls. These results are not in agreement with our previous finding that the polyamines in the whole brain were significantly increased in O.B. lesioned mice (2). The discrepancy in results is attributed to the difference of strains and of mice used time after operation.

In unoperated controls, the SPD level displayed considerable regional variation. The lowest concentration was observed in the cortex and the highest in the pons-medulla oblongata. Though the cercbellum contained the second highest level of SPD, its total polyamine was the greatest of all brain regions studied. The cortex, which had the lowest content of SPD, exhibited the second highest level of SPM. These results are in accord with the observation of Shaskan et al. (6).

The SPD level in the cortex significantly increased in O.B. lesioned rats compared with that of unoperated controls. No significant alteration in SPD level was produced in any examined region. The SP.M level in the striatum significantly decreased in O.B. lesioned rals compared with unoperated controls. In the cortex, there was no significant augmentation in the SPM level despite at marked increase in the SPD level.

The distribution of polyamine in each region of the brain differs. The ratio of SPD to SPM is high in the pons-medulla oblongata and low in the cortex suggesting that the function of the polyamines in the brain may be different from functions of these amines in other tissues. The ratio of SPD to SPM in adult rat liver and most organs is approximately $1(7,8)$. Russell et al. have shown that electrical stimulation of precentral gyrus in rhesus monkey was found to decrease the contents of both SPD and SPM by $25 \%$ with no detectable change in putrescine concentration. Moreover, they suggested that these amines may be involved in transmission phenomena (9). In the present work, the SPM concentration in the cortex increased and conversely the SPM concentration in the striatum fell in O.B. lesioned rats indicating that changes in brain polyamines are rather specific phenomena and do not occur in the case of all cations.

\section{REFERFNCES}

1) Tadano, T., Onoki, M. and Kisara, K.: Folia pharmacol. japon. 70, 9 (1974) (in Japanese);

2) Snklrad), T., Tadano, T., IMAI, M. avd Kisara, K.: Folia phamacol. japon. 70, 629 (1974) (in Japaneje); 3) Glowivski, J. And Iverest: N, L.I.: J. Neurochem. 13, 655 (1966); 4) Endo, Y. and Ogura, Y.: Europ. J. Pharmacol. 21, 293 (1973); 5) Satake, K., Okuyama, T., Ohashi, M. AND Shrivod, T.: J. Biochem. 47,654 (1960); 6) SHASKan, F.G., HARASZTI, J. AND SYNDFr, S.H.: J. Nelrochem. 20, 1443 (1970); 7) JANNE, J., Raina, A. AND Simes, M.: Acta physiol. scand. 62, 352 (1964); 8) NeISH, W.J.P. AND KAY, L.: Biochem. Pharmacol. 17, 497 (1968); 91 Russell, D.H., Gfelder, E., Marrov, L.J. and LeGendre, S.M. : J. Newrobiol. 5, 349 (1974) 